\title{
Pengaruh Literasi Finansial Berbasis Virtual Reality pada Kemampuan Berfikir Kritis Siswa
}

\author{
The Effect of Virtual Rality Based Financial Literation of Students \\ Critical Thinking Ability
}

Asri Ratna Sari

SMP 2 Banjarnegara

\begin{tabular}{l}
\hline ARTICLE INFO \\
\hline Article history: \\
DOI: \\
10.30595/pssh.v1i.74 \\
Submitted: \\
April 12, 2021 \\
Accepted: \\
June 10, 2021 \\
Published: \\
June 14, 2021 \\
\hline
\end{tabular}

Keywords:

Anxiety, COVID-19, Indonesian people

\begin{abstract}
This type of research is an experimental study consisting of two classes with different treatments. This study aims to determine (1) critical thinking skills of students who are taught using virtual reality-based financial literacy, (2) critical thinking abilities of students taught using power point media-based financial literacy, (3) the effect of learning using virtual reality-based financial literacy on students' critical thinking skills. The population of this study were students of class VII B as the experimental group and class $7 \mathrm{~A}$ as the control group, at SMP N 2 Banjarnegara in the odd semester of the 2020/2021 school year, the sample was using the simple random sampling method. The research data were analyzed using descriptive and inferential statistical analysis techniques. The results of descriptive statistical analysis are as follows: (1) The critical thinking ability of students who are taught using virtual reality-based financial literacy is in the high category with an average of 88 with a standard deviation of 12.836601 from a maximum score of 100, (2) Critical thinking skills students taught using virtual reality-based financial literacy are at an average of 66 with a standard deviation of 15.47284289 . From the results of inferential statistical analysis, Fvalue <Ftable $(0.6908436214<1.85)$ so that H0 is rejected or there is a significant effect of learning using virtual reality-based financial literacy on students' critical thinking skills. Observations show that students are more interested in financial literacy using virtual reality because students feel the sensation of interacting with the real environment, visualizing abstract things to be easy to understand and increasing their imagination.
\end{abstract}

This work is licensed under a Creative Commons Attribution 4.0 International License.

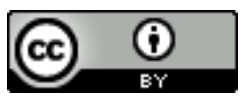

\author{
Corresponding Author: \\ Asri Ratna Sari \\ Junior High School 2 of Banjarnegara \\ Jalan Tentara Pelajar No.31 Banjarnegara, Jawa Tengah, Indonesia \\ Email: asri01ratnasari@gmail.com
}

\section{INTRODUCTION}

Education includes various fields that work together, one of which is Social Sciences (IPS). Social studies is a field of education that aims to synergize various subjects into life skills, which students need to master. Therefore, it consists of various social sciences. Social science must be revitalized in such a way that it is easy for students to learn or undertake in accordance with their level of psychological development at school, and to encourage the level of thinking of students. [1]

The thinking ability of students consists of various aspects, one of which is the ability to think critically. Critical thinking skills need to be developed, because thinking is basically a characteristic and superiority of humans. Education should focus on high order thinking skills and will produce active students who are not only good at memorizing imitation, but also skilled at solving critical and creative problems. 
In its implementation, the PJJ process does not support the achievement of students' competencies, let alone leading to critical thinking. Teachers also often find it difficult to describe learning resources or resources, which are only modules and teaching materials through social media. With limited time and lack of explanation, resulting in inaccurate achievement of student competencies and target learning demands. Therefore, researchers as social studies teachers must quickly resolve these weaknesses and start to develop and change the learning process, according to the situation in order to achieve the competence of students.

Virtual media literacy, in this case financial literacy, is expected to make students proactive, interesting and challanging to learn, thus spurring to develop their critical thinking skills. Thus, it is hoped that through learning using virtual reality-based financial literacy media students will have the opportunity to develop their critical thinking skills, to get used to solving problems, especially financial and useful in everyday life, as well as increase their financial literacy and become a literate generation. [2]

\section{RESEARCH METHOD}

All the data were collected by the researcher using google form and spread massively by social media. Before completing the self-administered questionnaires, participants were asked to read the information sheet and mark an agreement consent form. Participants were given some minutes to complete whole parts of the questionnaire. Besides demographic data, the resulting self- administered questionnaire included questions addressing anxiety. All of the participants results were recorded in google sheet automatically. The data were coded, validated and analyzed using SPSS (Version 21). Descriptive statistics were used to measure the contribution of demographic data (numbers, mean, percentage and standard deviation) including age, living status, working type, educational level, and anxiety. The study received the approval of the $n$ this study, to test the critical thinking skills instrument of students, the content validity test was carried out. Content validity is used for instruments in the form of tests, this test can be done by comparing the contents of the instrument with the subject matter being taught. For instruments that will measure the effectiveness of program implementation, this validity test can be done by comparing the contents of the instrument with the content or design. [3]

The independent variable instrument also influences the success of a virtual-based financial literacy media study which is used as a treatment, is financial literacy which is modified so that it contains measurable literate behavior messages.

The process of giving treatment starts from preparing a lesson plan, virtual reality template scenario, creating a game scene with the Millealab application, creating a class and determining the game method on students' smartphones, continuing using the Shinta VR application and determining the game time. The data analysis technique used to analyze the research data is inferential statistical techniques. Activities that include inferential statistical analysis are determining hypothesis testing using the $t$ test of variance. Before testing the hypothesis, there are several requirements that must be met and proven, namely the data to be analyzed must be normally distributed or test for normality. In addition, to find out that the analyzed data was homogeneous, the variance homogeneity test was carried out. [4]

\section{RESULTS AND DISCUSSIONS}

The data description of the students' critical thinking ability scores describes the mean standard deviation of variance, maximum value, minimum value, range, number of classes and the length of the interval class. The recapitulation of the results of the data description can be seen in table 1 below

Table 1.Data description of students' critical thinking abilities in the experimental group and the control group

\begin{tabular}{ccc}
\hline Analysis result & Experimental group & Control group \\
\hline Mean & 88 & 66 \\
Standar Deviation & 12,836601 & 15,47284289 \\
Variance & 119,3296671 & 136,0359691 \\
The highest score & 100 & 100 \\
Lowest score & 60 & 40 \\
Range & 40 & 60 \\
Many classes & 6 & 6 \\
Class length & 7 & 7 \\
\hline
\end{tabular}

Based on these data, it is known that the data on critical thinking skills of experimental group students who carry out virtual reality-based financial literacy learning activities has an average of 88, a standard deviation of 12.836601, a variant of 119.3296671 . The highest score achieved by students is 100 , from the highest score that might 
be achieved by 100 or reaching the highest score, the lowest score achieved by students is 60 of the possible scores that are achieved, namely 0, a range of 40, many interval classes are 6 and the length of the interval class is 7 .

Data on critical thinking skills of control group students who carry out learning activities using powerpoint media has an average of 66, a standard deviation of 15.47284289, a variant of 136.0359691, the highest score achieved by students is 100 from the highest possible score is 100 , the lowest score achieved by students is 40 from the lowest possible score is 0 , the range is 60 , many interval classes are 6 , and the length of the interval class is 7.

Based on this description, it can be seen that the experimental group that was taught using virtual realityfinancial literacy media had an average critical thinking ability of students higher than the control group, which carried out learning activities using power point media.Before testing the hypothesis, a number of prerequisite tests must be carried out on the distribution of data, which includes data normality test and variance homogeneity test of students' critical thinking ability data.

The data normality test was carried out to prove that the two samples were normally distributed. The calculation of the normality test can be presented in table 2 below

Table 2. Post-Test Data Normality Test Results

\begin{tabular}{lllll}
\hline No & Sample & $\begin{array}{c}\text { the biggest difference } \\
\text { Sn1 (X)-Sn2(X) }\end{array}$ & KD table & Information \\
\hline $1 \quad$ Experimental group & 0,1316460184 & 0,246 & Normally distributed \\
2 & Control group & 0,2006115357 & 0,246 & Normally distributed
\end{tabular}

Based on the test results using the Kolmogorov-Smirnov, the biggest difference between Sn1 (X) -Sn2 (X) was 0.131640184 and the KD table at 5\% Alfa was 0.246. This means that $\mathrm{Sn} 1(\mathrm{X})-\mathrm{Sn} 2(\mathrm{X})$ in both groups is smaller than the KD table, so that the posttest data for the experimental group and the control group are normally distributed.

After carrying out the normality test, the variance homogeneity test was then carried out. The homogeneity test of the variance data on students 'critical thinking abilities was analyzed by using the Ftest, with the criteria for both groups to have a homogeneous variance if Fcount <Ftable. The results of the variance homogeneity test data on students' critical thinking abilities can be seen in table 3 below.

Table 3. Results of the homogeneity test of the post test data variants

\begin{tabular}{|c|c|c|c|c|}
\hline No & Group & Fcount & Ftable & Information \\
\hline 1 & Experimental group & 0,6908436214 & 1.85 & homogen \\
\hline 2 & Control group & 0,6908436214 & 1.85 & homogen \\
\hline
\end{tabular}

From the calculation results obtained F count 0.6908436214 the price is then compared with the $\mathrm{F}$ table price obtained from the table of values in the F distribution, with the DK numerator 29 and DK denominator 29 at $\alpha$ $5 \%$. Based on the table of values in the F distribution, it is obtained that the F table is 1.85 . Based on the results of the calculation, the calculated $F$ value is less than or more than $\mathrm{f}$ table $(0.6908436214<1.85)$ so Ho is rejected.

This means that the data variance of students' critical thinking abilities in the experimental group and the control group is the same or homogeneous. Based on the results of the prerequisite test, namely the normality test, data and the homogeneity test of variance, it can be seen that the data is normally distributed and has a homogeneous variance.

To test the hypothesis, it is done by using the t test with the polled variant formula which is presented in table 4 below

Table 4 the results of the T test analysis on the post test data

\begin{tabular}{lllll}
\hline No & Sample & tcount & ttable & Information \\
\hline 1 & Experimental group & 34,51607455 & 2,051830516 & Ho rejected
\end{tabular}




2 Control group 34,51607455 Ho rejected
Based on the results of data analysis, it is obtained t count of 34.51607455 , the price is then compared with
the $t$ table price. The value of t table is obtained from the table of values in the $t$ distribution with 27 degrees of freedom
and $\alpha 5 \%$. Based on the table of values in the $t$ distribution, the $t$ table price is 2.051830516 , because $t$ count is greater
than $\mathrm{t}$ table $(34.51607455>2.051830516)$ so Ho is rejected or Ha is accepted.
This means that there is an effect of virtual reality-based financial literacy on the critical thinking skills of students in
class $7 \mathrm{~B}$ of SMP Negeri 2 Banjarnegara in 2020/2021.
Learning in the experimental group that uses virtual reality-based financial literacy is actually superior,
this happens because virtual reality-based financial literacy is virtual reality media, in which there is technology to
create behavioral designs about financial literacy, which are manifested in virtual or virtual worlds. using a display
device and stimulant sensors to cause immersive effects for the user.

\section{CONCLUSION}

Based on the results of the analysis of the $\mathrm{T} \mathrm{dk} 27$ and $\alpha 5 \%$ test, the $\mathrm{t}$ count is $34.51607455>$ from the table 2.051830516, so Ho which says there is no influence of virtual reality-based financial literacy media on the critical thinking skills of 7B grade students of SMP Negeri 2 Banjarnegara academic year 2020/2021 was rejected.

Based on this description, it can be concluded that virtual reality-based financial literacy has an effect on increasing the critical thinking skills of 7B grade students of SMP Negeri 2 Banjarnegara in the 2020/2021 school year.

\section{Acknowledgements}

The author would like to thank the Principal of SMP N 2 Banjarnegara for allowing and giving encouragement to carry out this research. These thanks are conveyed to colleagues at mgmp IPS Banjarnegara who have provided assistance and advice during the research. The utmost thanks and appreciation are addressed to all respondents and teachers of SMP N 2 Banjarnegara who have been kind during the data collection process.

\section{REFERENCES}

Miftahudin.

$$
\text { Revitalisasi IPS dalam }
$$

nglobal.journaltribakti.ac.id,https://doi.org/10.33367/tribakti.v2112.269.Miftahudin.2016

[2] Fahri Abdullah. Pengertian literasi, tujuan dan jenisnya: Ruang guru. 2021 Millealab. Panduan penggunaan virtual reality. 2020

[3] Sugiyono. Metode Penelitian Kuantitatif. Bandung: Alvabeata. 2017.

[4] Heni subandiyah. Pembelajaran literasi dalam mata pelajaran bahasa Indonesia. paramasastra vol 2 Nomor 12015 http:;//dx.doi.org/10.26740/paramaV2n1.p/25p jurnal pendidikan anak usia dini Universitas Pendidikan Ganesha Volume 6 Nomor $1: 2018$ 